Article

\title{
Screening and Evaluation of Essential Oils from Mediterranean Aromatic Plants against the Mushroom Cobweb Disease, Cladobotryum mycophilum
}

\author{
Francisco J. Gea ${ }^{1, *}{ }^{(\mathbb{C},}$, María J. Navarro ${ }^{1}$, Mila Santos ${ }^{2}$, Fernando Diánez ${ }^{2}$ \\ and David Herraiz-Peñalver ${ }^{3}$ \\ 1 Centro de Investigación, Experimentación y Servicios del Champiñón (CIES), 16220 Quintanar del Rey, \\ Cuenca, Spain; mjnavarro.cies@dipucuenca.es \\ 2 Departamento de Agronomía, Escuela Politécnica Superior, Universidad de Almería, 04120 Almería, Spain; \\ msantos@ual.es (M.S.); fdianez@ual.es (F.D.) \\ 3 Centro de Investigación Agroforestal de Albaladejito (CIAF), Instituto Regional de Investigación y Desarrollo \\ Agroalimentario y Forestal de Castilla-La Mancha (IRIAF), 16194 Cuenca, Spain; dherraiz@jccm.es \\ * Correspondence: fjgea.cies@dipucuenca.es; Tel.: +34-967-496-198
}

Received: 10 September 2019; Accepted: 15 October 2019; Published: 18 October 2019

\begin{abstract}
The main aim of this study was to evaluate the use of essential oils (EOs) as an alternative to synthetic fungicides used in the control of cobweb disease of button mushroom (Agaricus bisporus) caused by Cladobotryum mycophilum. The EOs used were obtained by hydrodistillation from five Mediterranean aromatic species (Lavandula $\times$ intermedia, Salvia lavandulifolia, Satureja montana, Thymus mastichina, and Thymus vulgaris), analyzed by gas chromatography, and tested in vitro for their antifungal activity against $C$. mycophilum. In vitro bioassays showed that the EOs obtained from T. vulgaris and S. montana $\left(\mathrm{ED}_{50}=35.5\right.$ and $42.8 \mathrm{mg} \mathrm{L}^{-1}$, respectively) were the most effective EOs for inhibiting the mycelial growth of C. mycophilum, and were also the most selective EOs between C. mycophilum and A. bisporus. The in vivo efficacy of T. vulgaris and S. montana EOs at two different concentrations (0.5 and $1 \%$ ) were evaluated in two mushroom growing trials with C. mycophilum inoculation. The treatments involving T. vulgaris and S. montana EOs at the higher dose ( $1 \%$ concentration) were as effective as fungicide treatment. The effect of these EOs on mushroom productivity was tested in a mushroom cropping trial without inoculation. They had a strong fungitoxic effect at the first flush. However, a compensatory effect was observed by the end of the crop cycle and no differences were observed in biological efficiency between treatments. The main compounds found were carvacrol and $p$-cymene for S. montana, and $p$-cymene and thymol for T. vulgaris. These results suggest that T. vulgaris and S. montana EOs may be useful products to manage cobweb disease if used as part of an integrated pest management (IPM) program.
\end{abstract}

Keywords: Agaricus bisporus; antifungal activity; biofungicides; mushroom cultivation; Satureja montana; Thymus vulgaris

\section{Introduction}

Cobweb disease, caused by the mycopathogenic fungus Cladobotryum mycophilum (Oudem.) W. Gams \& Hooz., is found in all mushroom-growing countries worldwide. The disease is prevalent especially in white button mushroom (Agaricus bisporus (Lange) Imbach) [1-5], king oyster mushroom (Pleurotus eryngii (DC.:Fr.) Quél.) [6-8], and oyster mushroom (Pleurotus ostreatus (Jacq.) P. Kumm.) [9]. Cobweb disease is associated with final flushes and conditioned by the season. The pathogen develops 
into a cottony growth of mycelium, colored grey to white, which spreads over the casing layer and mushrooms. Cobweb mycelium becomes dense and sometimes develops a rosy red or yellow hue. The pathogen may grow over primordia and mushrooms, affecting the salability of the product [10]. Methods to control cobweb include strict hygiene measures to prevent dispersion of the conidia and the application of fungicides, mainly prochloraz and metrafenone [11-13]. However, the use of conventional chemical fungicides is gradually being limited due to its negative effects on human health, environmental safety, pathogen resistance, etc. Therefore, improvements in the hygiene conditions of farming facilities, as well as a better understanding of the new, environment-friendly, and effective control methods are necessary to minimize the use of chemicals in the mushroom industry.

In order to develop alternatives to chemical agents within an integrated management strategy for cobweb disease, the possible use of essential oils (EOs) would present many advantages in terms of sustainability, low persistence in the environment, biological activity, mode of action, effectiveness, and toxicity. For many years, EOs have been studied as sources of natural antifungal products and they have been screened for their potential uses as alternative remedies for the treatment of many phytopathogenic fungi [14-16]. More specifically, some EOs have also been tested as control agents against the most important diseases of white button mushroom. The EOs from Cinnamomun zeylanicum Blume, Origanum vulgare L., Syzygium aromaticum (L.) Merr. \& L.M. Perry, Thymus vulgaris L., Zataria multiflora Boiss, and Satureja hortensis L. showed strong in vitro activity against Lecanicillium fungicola var. fungicola (Preuss) Zare \& W. Gams [17-19]; Lippia citriodora (Cav.) Kunth, Cymbopogon citratus (D.C) Stapf, and T. vulgaris EOs were found to substantially inhibit the growth of Mycogone perniciosa (Magnus) Delacroix [20]; and S. aromaticum EO also exhibited strong in vitro inhibition against C. mycophilum [21]. Melaleuca alternifolia (Maiden \& Betchee) Cheel essential oil was less toxic in vitro than prochloraz-Mn against Cladobotryum dendroides (Bull.:Fr.) W. Gams \& Hooz., although in in vivo trials it caused a significant reduction in cobweb disease levels compared with a control without fungicide [22]. Therefore, these studies suggest that EOs can be considered as suitable biocontrol agents for the control of mushroom diseases, particularly the cobweb disease.

Moreover, it must be borne in mind that the cultivation of aromatic plants is an important agricultural activity in many parts of Spain, especially in certain zones of Castilla-La Mancha, near the most important mushroom cultivation centres. Several preliminary studies focused on native Mediterranean aromatic species (Lavandula spp., Thymus spp., Salvia lavandulifolia Vahl, Rosmarinus officinalis L., Santolina chamaecyparissus L., Hyssopus officinalis L., and Satureja montana L.), adapted to local environmental conditions, have been carried out. In this respect, antifeedant, insecticidal, phytotoxic, nematicidal, antibacterial, and antifungal activities of EOs from the above-mentioned species have been reported $[23,24]$. However, many factors including the origin of the cultivar or variety, environment (climatic, seasonal, and geographical), type of plant material used, plant nutrition, application of fertilizers, and the method of extraction have influence not only in the identity of main compounds of an essential oil but also in their percentage, and thereby might affect its biocidal properties $[25,26]$.

The aim of this study was to: (i) characterize the chemical composition of five EOs from Mediterranean aromatic plants belonging to the Lamiaceae family, such as Lavandula $\times$ intermedia Emeric ex Loiseleur, Salvia lavandulifolia Vahl, Satureja montana L., Thymus mastichina L., and Thymus vulgaris L.; (ii) determine the effectiveness of the above-mentioned EOs in cobweb control by in vitro antifungal activity bioassays and in vivo mushroom trials involving inoculation with C. mycophilum; and (iii) test the toxicity of these EOs to A. bisporus mycelium and/or mushroom yield.

\section{Materials and Methods}

\subsection{Plant Material}

The species used for EO extraction (L. × intermedia (lavandin), S. lavandulifolia (Spanish sage), S. montana (savory), T. mastichina (white thyme), and T. vulgaris (thyme)) were cultivated in the 
experimental fields of CIAF Albaladejito-IRIAF (Cuenca, Spain). Harvests of aerial parts from plants (inflorescences, leaves, and stems) were made at the flowering phenological stage.

\subsection{Essential Oil Extraction}

The plant material was dried in an environmental chamber at $28{ }^{\circ} \mathrm{C}$ until a constant weight is obtained before extraction. Samples were hydrodistilled using a Clevenger-type apparatus for 4 hours according to the method recommended in the European Pharmacopoeia [27].

\subsection{Components Identification and Quantification}

The chemical components of the EO were identified by gas chromatography. GC-FID analyses were carried out using a Varian 400-GC gas chromatograph operated with a split/splitless injector (Varian Inc., Palo Alto, CA, USA). Column (non-polar): VF-5ms (cross-linked phenyl-methyl siloxane), $60 \mathrm{~m} \times 0.25 \mathrm{~mm} \times 0.25 \mu \mathrm{m}$ film thickness (Varian Inc., Palo Alto, CA, USA). Temperature program: from $70-95{ }^{\circ} \mathrm{C}$ at $3{ }^{\circ} \mathrm{C} / \mathrm{min}$ and from $95-240{ }^{\circ} \mathrm{C}(5 \mathrm{~min})$ at $4{ }^{\circ} \mathrm{C} / \mathrm{min}$. Injection temperature: $250{ }^{\circ} \mathrm{C}$. Injection volume: $0.5 \mu \mathrm{L}$. Carrier gas: $\mathrm{He}(1 \mathrm{~mL} / \mathrm{min})$. Injection mode: split (100:1). FID $\left(300^{\circ} \mathrm{C}\right)$ : $\mathrm{H}_{2}$ flow, $35 \mathrm{~mL} / \mathrm{min}$; air flow, $300 \mathrm{~mL} / \mathrm{min}$; and make up flow, $29 \mathrm{~mL} / \mathrm{min}$. Sampling rate: $50 \mathrm{~ms}$. Relative retention times and Kovats Index of corresponding reference standards (Acros Organics BVBA/SPRL, Fisher Scientific S.A., and Sigma Aldrich Química A.) were used to identify the major components using the Adams library [28]. The relative amounts of individual components were calculated according to the area of the chromatographic peaks using Galaxie ${ }^{\circledR}$ Chromatography software (Varian Inc., Walnut Creek, CA, USA).

\subsection{Fungal Isolates}

Six Cladobotrym mycophilum isolates obtained from mushroom farms located in Castilla-La Mancha and La Rioja (Spain) were used in vitro to test for antifungal activity and selectivity index of five EOs. Isolates were collected between 2015 and 2017 from Agaricus bisporus crops with symptoms of cobweb disease, maintained on potato dextrose agar (PDA; Oxoid, Basingstoke, England) medium at $22^{\circ} \mathrm{C}$ in darkness, and characterized morphologically and molecularly $[10,29,30]$. Two commercial mushroom strains (Mispaj 400 (Mispaj S.L., Pradejón, La Rioja, Spain) and Gurelan 90 (Gurelan S. Coop., Huarte, Pamplona, Spain)) were used to determine the toxic effect of the EOs on A. bisporus mycelium.

\subsection{In Vitro Antifungal Activity and Selectivity Index of the Essential Oils on Mycelium Growth of Cladobotryum Mycophilum and Agaricus bisporus}

The antifungal activities of the EOs against $C$. mycophilum and A. bisporus were calculated by in vitro sensitivity assays, with slight modifications $[8,13]$. The five EOs (containing $0.01 \%$ Tween 20) from each plant sample were added to molten sterile malt extract agar (MEA) medium at $45^{\circ} \mathrm{C}$ prior to solidification. The EO concentrations selected for the C. mycophilum isolates were: Lavandula $\times$ intermedia $\left(46,92,183,366\right.$, and $\left.732 \mathrm{mg} \mathrm{L}^{-1}\right)$, Thymus mastichina $(325,650,1300,2600$, and $5200 \mathrm{mg}$ $\left.\mathrm{L}^{-1}\right)$, Thymus vulgaris $\left(5,9,18,36\right.$, and $\left.72 \mathrm{mg} \mathrm{L}^{-1}\right)$, Salvia lavandulifolia $(83,165,330,660$, and $1320 \mathrm{mg}$ $\left.\mathrm{L}^{-1}\right)$, and Satureja montana $\left(10,21,41,82\right.$, and $\left.164 \mathrm{mg} \mathrm{L}^{-1}\right)$. All EO-amended media were prepared a maximum of $24 \mathrm{~h}$ before use. Control consisted of unamended plates. Four replicates were used per combination of isolate and $\mathrm{EO}$ concentration. The experiment was repeated twice.

The percentage of relative inhibition (PI) of mycelial growth was calculated using the formula: (PI = $100(C-T) / C$, where $C=$ rate of growth of the control and $T=$ rate of growth in treated dishes). $E_{50}$ values (mg L ${ }^{-1}$ of essential oil inhibiting radial mycelial growth by $50 \%$ ) were calculated using the data analysis software PoloPlus, Probit, and Logit Analysis (LeOra Software Company, Petaluma, CA, USA) [31].

The in vitro antifungal activity of these EOs on A. bisporus was evaluated using essential oil-amended agar-compost medium [32], following the methodology described for the pathogen. The studied EOs (containing $0.01 \%$ Tween 20) were added to produce final concentrations of 10, 100, 1000 , and $10,000 \mathrm{mgL}^{-1}$. The unamended medium was used as a control. A mushroom spawn grain 
covered with actively growing mycelium of two commercial mushroom strains were placed on the medium and incubated for 10 days at $25^{\circ} \mathrm{C}$ in the dark.

A selectivity index (SI) for each essential oil was calculated as the ratio between the mean $\mathrm{ED}_{50}$ values for the $C$. mycophilum isolates tested and the corresponding mean $\mathrm{ED}_{50}$ values were estimated for the two commercial A. bisporus strains. Selectivity indices lower than 0.1 express acceptable selective toxicity between the pathogen and the host [33].

$\mathrm{ED}_{50}$ values were examined using analysis of variance (ANOVA). $\mathrm{ED}_{50}$ values, where necessary, were transformed by $\log (x+1)$ before analysis and were back-transformed for the tables. Mean comparisons were performed using the Fisher's LSD (least significant difference) test to examine if differences were significant at $p<0.05$. Statistical analyses were made using Statgraphics Centurion XV (Statistical Graphics Corp., Princeton, NJ, USA).

\subsection{Effectiveness of EOs Treatments in Mushroom Growing Trials with Cladobotryum Mycophilum Inoculation}

The effectiveness of EOs to control cobweb disease was tested in two cropping trials (A and B) carried out in experimental mushroom growing rooms $\left(20 \mathrm{~m}^{3}\right)$, according to the standard practices used in mushroom farms in Spain. In each trial, experimental trays $\left(0.15 \mathrm{~m}^{2}\right)$ filled with $10 \mathrm{~kg}$ commercial phase III compost (Champinter SCL, Villamalea, Albacete, Spain) and spawned at $1 \%$ with the commercial mycelium Sylvan ${ }^{\circledR}$ A15 (Sylvan Inc., Kittanning, PA, USA) were used. The trays were arranged in shelves at three different levels in a completely randomized block design. Each trial was conducted using 42 trays, 36 of which were inoculated with C. mycophilum, while the remaining 6 trays were sprayed with water and used as uninoculated control. The 36 inoculated trays were divided into five treatments and an inoculated control, with six replicates per treatment.

On casing day (day 0) of the cropping cycle, the compost was cased with a peat-based casing as a 30-35 mm thick layer (5.5 L per experimental tray). The environmental conditions were: compost temperature of about $24-26^{\circ} \mathrm{C}, 93-98 \%$ relative humidity (RH) with $8000 \rightarrow 3200 \mathrm{ppm}$ carbon dioxide $\left(\mathrm{CO}_{2}\right)$. Inoculation was done eleven days after casing by watering $20 \mathrm{~mL}$ per tray of a conidial suspension of $C$. mycophilum $\left(10^{6}\right.$ conidia $\left.\mathrm{m}^{-2}\right)$ onto the surface of the casing layer in the inoculated treatments. The non-inoculated control was sprayed with sterile distilled water. The C. mycophilum isolate CS1, collected in September 2016 in a mushroom farm from Casasimarro (Castilla-La Mancha, Spain), was used as an inoculum and prepared on the day of inoculation. The concentration of the conidial suspension was determined using a hemocytometer and diluted in sterile distilled water to $7.5 \times 10^{3}$ conidia $\mathrm{mL}^{-1}$.

Based on the in vitro antifungal activity results given in Table 3, the Satureja montana and Thymus vulgaris EOs were selected. Essentials oil formulations were diluted in tap water to reach $0.5 \%$ (trial A) and 1\% (trial B) concentration (containing 0.01\% Tween 20) and added as a single drench application, at a rate of $150 \mathrm{~mL}$ per tray. For each of the EOs selected, there were two treatments and six replicate trays per treatment. The first treatment (BI: before inoculation) was applied 1 day before inoculating with conidia of C. mycophilum, while the second treatment (AI: after inoculation) was applied 2 days after inoculation. There were three controls: first, a non-inoculated control (C), in which drench applications were $150 \mathrm{~mL}$ tap water per tray; second, an inoculated control (IC), each tray receiving a $20 \mathrm{~mL}$ conidial suspension of $C$. mycophilum, in which irrigation was by water alone; and third (IMFC), also inoculated, but including the fungicide Vivando ${ }^{\circledR}$ (metrafenone $50 \%$ SC, BASF Crop Protection Spain, Barcelona, Spain) at $1 \mathrm{~mL} \mathrm{~L}^{-1}$ per $\mathrm{m}^{2}$ on day 4 , at a rate of $150 \mathrm{~mL}$ per tray (Table 1). 
Table 1. Treatments applied in the mushroom crop trials.

\begin{tabular}{|c|c|c|c|}
\hline Trials & Code & $\begin{array}{l}\text { Inoculation } \\
\left(10^{6} \text { conidia } \mathrm{m}^{-2}\right)^{\text {a }}\end{array}$ & Treatment $^{b}$ \\
\hline $\mathrm{A}, \mathrm{B}$, and C & $\mathrm{C}$ & No & Only tap water. \\
\hline$A$ and $B$ & IMFC & Yes & Vivando ${ }^{\circledR}$ at $1 \mathrm{ml} \mathrm{L}^{-1}$ on day 4. \\
\hline$A$ and $B$ & IC & Yes & Only tap water. \\
\hline A & IEO1B & Yes & $\begin{array}{l}\text { Satureja montana essential oil at } 0.5 \% \text { applied } 1 \text { day before } \\
\text { inoculation with Cladobotryum mycophilum, on day } 10 .\end{array}$ \\
\hline A & IEO1A & Yes & $\begin{array}{l}\text { Satureja montana essential oil at } 0.5 \% \text { applied } 2 \text { days after } \\
\text { inoculation with Cladobotryum mycophilum, on day } 13 \text {. }\end{array}$ \\
\hline A & IEO3B & Yes & $\begin{array}{l}\text { Thymus vulgaris essential oil at } 0.5 \% \text { applied } 1 \text { day before } \\
\text { inoculation with Cladobotryum mycophilum, on day } 10 \text {. }\end{array}$ \\
\hline A & IEO3A & Yes & $\begin{array}{l}\text { Thymus vulgaris essential oil at } 0.5 \% \text { applied } 2 \text { days after } \\
\text { inoculation with Cladobotryum mycophilum, on day } 13 \text {. }\end{array}$ \\
\hline B & IEO1B & Yes & $\begin{array}{l}\text { Satureja montana essential oil at } 1 \% \text { applied } 1 \text { day before } \\
\text { inoculation with Cladobotryum mycophilum, on day } 10 .\end{array}$ \\
\hline B & IEO1A & Yes & $\begin{array}{l}\text { Satureja montana essential oil at } 1 \% \text { applied } 2 \text { days after } \\
\text { inoculation with Cladobotryum mycophilum, on day } 13 \text {. }\end{array}$ \\
\hline B & IEO3B & Yes & $\begin{array}{l}\text { Thymus vulgaris essential oil at } 1 \% \text { applied } 1 \text { day before } \\
\text { inoculation with Cladobotryum mycophilum, on day } 10 .\end{array}$ \\
\hline B & IEO3A & Yes & $\begin{array}{l}\text { Thymus vulgaris essential oil at } 1 \% \text { applied } 2 \text { days after } \\
\text { inoculation with Cladobotryum mycophilum, on day } 13 \text {. }\end{array}$ \\
\hline $\mathrm{C}$ & MFC & No & Vivando ${ }^{\circledR}$ at $1 \mathrm{~mL} \mathrm{~L}^{-1}$ on day 4. \\
\hline $\mathrm{C}$ & EO1B & No & Satureja montana essential oil at 1\% applied on day 10 . \\
\hline $\mathrm{C}$ & EO1A & No & Satureja montana essential oil at 1\% applied on day 13. \\
\hline $\mathrm{C}$ & EO3B & No & Thymus vulgaris essential oil at $1 \%$ applied on day 10 . \\
\hline $\mathrm{C}$ & EO3A & No & Thymus vulgaris essential oil at $1 \%$ applied on day 13 . \\
\hline
\end{tabular}

In each trial, three flushes of mushrooms were harvested. Disease incidence (DI) was calculated as a percentage value, based on the ratio of the crop area colonized by cobweb in each treatment to the total colonized and non-colonized crop area. The affected area by cobweb was left uncovered for 24 hours. After that, this area was covered with a piece of damp paper and salt to avoid pathogen dispersion [11,12]. The DI in the different trays was related to the uninoculated control disease incidence average using the Abbot's formula correction:

$$
\text { DIcorr }=(\text { DIexp }- \text { DIcont }) /(1-\text { DIcont }),
$$

where DIexp $=$ experimental treatment disease incidence, and DIcont $=$ mean uninoculated control disease incidence [34]. The effectiveness of EOs treatments was calculated based on the DI using Abbott's formula [35]:

$$
\text { Effectiveness }(\%)=[(\text { Din-cont }- \text { DIcorr }) / \text { DIin-cont }] \times 100,
$$

where DIin-cont $=$ disease incidence of the inoculated control and DIcorr $=$ corrected disease incidence of the treatment.

The disease incidence and the effectiveness of treatments were examined using ANOVA. Mean comparisons were performed using the Fisher's LSD test to examine if differences were significant at $p<0.05$. Statistical analyses were made using Statgraphics Centurion XV (Statistical Graphics Corp., Princeton, NJ, USA).

\subsection{Effect of EOs Treatments on Agaricus bisporus Yield}

The effect of essential oils on A. bisporus yield was determined in a third cropping trial (trial C). This trial was set up under conditions identical trial B. No conidial suspensions were applied in the treatments (Table 1). The experiment was a randomized complete block design with five replicates. The effect of essential oils and metrafenone treatments on A. bisporus yield was assessed by reference 
to daily recorded mushroom production ( $\mathrm{kg} \mathrm{m}^{-2}$ per flush and total yield). The effect of treatments on mushroom productivity was evaluated by the biological efficiency of the crop and calculated as the percentage ratio of the fresh weight of total yield of harvested mushrooms over the weight of dry substrate at spawning and expressing the fraction as $\mathrm{kg} / 100 \mathrm{~kg}$ compost. In addition, the earliness (days to first harvest for each treatment) was expressed as the number of days between casing and harvesting of the first flush.

An ANOVA was used to test for the effect of treatment and the different yield parameters. Mean comparisons were performed using the Fisher's LSD test to examine if differences were significant at $p<0.05$. Data were analyzed separately for each flush. Statistical analyses were made using Statgraphics Centurion XV (Statistical Graphics Corp., Princeton, NJ, USA).

\section{Results}

\subsection{Chemical Composition of the Essential Oils}

The chemical composition of the main compounds of the five EOs is shown in Table 2. Linalyl acetate $(34.20 \%)$ was the most abundant component, followed by linalool $(28.75 \%)$, camphor $(8.49 \%)$, and 1,8-cineole $(6.90 \%)$, in $L . \times$ intermedia $\mathrm{EO}$. The most abundant compound in S. lavandulifolia EO was 1,8-cineole (20.90\%), followed by $\beta$-pinene $+\beta$-myrcene $(13.99 \%)$, camphor $(12.60 \%)$, and $\alpha$-pinene $(11.39 \%)$. The main components of $S$. montana EO were carvacrol $(17.22 \%), p$-cymene $(11.54 \%)$, and camphor $(10.14 \%)$. In T. mastichina EO, 1,8-cineole $(44.57 \%)$ and linalool $(29.89 \%)$ were the major components, while the main components of $T$. vulgaris EO were p-cymene $(29.67 \%)$ and thymol (25.78\%).

Table 2. Percentages of the main compounds of the essential oils from Lavandula $\times$ intermedia, Salvia lavandulifolia, Satureja montana, Thymus mastichina, and Thymus vulgaris.

\begin{tabular}{|c|c|c|c|c|c|c|c|}
\hline Main Compounds ${ }^{a}$ & $\mathrm{KI}^{\mathrm{b}}$ & $\mathrm{RT}^{\mathrm{c}}$ & $\begin{array}{l}\text { Lavandula } \times \\
\text { intermedia }\end{array}$ & $\begin{array}{l}\text { Salvia } \\
\text { lavandulifolia }\end{array}$ & $\begin{array}{l}\text { Satureja } \\
\text { montana }\end{array}$ & $\begin{array}{l}\text { Thymus } \\
\text { mastichina }\end{array}$ & $\begin{array}{l}\text { Thymus } \\
\text { vulgaris }\end{array}$ \\
\hline$\alpha$-Pinene & 943 & 11.40 & $t^{d}$ & 11.39 & 7.86 & 2.33 & 1.73 \\
\hline $\begin{array}{l}\beta \text {-Pinene }+ \\
\beta \text {-Myrcene }\end{array}$ & 991 & 12.97 & 1.22 & 13.99 & 8.40 & 4.42 & 2.68 \\
\hline$p$-Cymene & 1033 & 14.52 & $\mathrm{t}$ & $\mathrm{t}$ & 11.54 & $\mathrm{t}$ & 29.67 \\
\hline$\gamma$-Terpinene & 1066 & 15.68 & $-\mathrm{e}$ & 1.4 & 6.79 & $\mathrm{t}$ & 7.55 \\
\hline Linalool & 1102 & 17.12 & 28.75 & $\mathrm{t}$ & 2.1 & 29.86 & 4.59 \\
\hline Camphor & 1165 & 19.32 & 8.49 & 12.60 & 10.14 & - & 1.54 \\
\hline$\alpha$-Terpineol & 1206 & 20.84 & $\mathrm{t}$ & $\mathrm{t}$ & $\mathrm{t}$ & 3.60 & $\mathrm{t}$ \\
\hline Linalyl acetate & 1254 & 22.45 & 34.20 & - & - & $\mathrm{t}$ & $\mathrm{t}$ \\
\hline
\end{tabular}

${ }^{a}$ Compounds listed in order of elution from an HP-5 column. ${ }^{b}$ Kovats index. ${ }^{c}$ Retention time (minutes). ${ }^{d}$ Traces.

e Not detected.

\subsection{In Vitro Antifungal Activity and Selectivity Index of the Essential Oils on Mycelium Growth of} Cladobotryum mycophilum and Agaricus bisporus

The most effective essential oils for inhibiting the in vitro mycelial growth of $C$. mycophilum were T. vulgaris $\left(\mathrm{ED}_{50}=35.5 \mathrm{mg} \mathrm{L}^{-1}\right)$ and S. montana $\left(\mathrm{ED}_{50}=42.8 \mathrm{mg} \mathrm{L}^{-1}\right)$. In contrast, $L . \times$ intermedia $\left(\mathrm{ED}_{50}\right.$ $\left.=784.2 \mathrm{mg} \mathrm{L}^{-1}\right)$, T. mastichina $\left(\mathrm{ED}_{50}=627.3 \mathrm{mg} \mathrm{L}^{-1}\right)$, and S. lavandulifolia $\left(\mathrm{ED}_{50}=598.4 \mathrm{mg} \mathrm{L}^{-1}\right) \mathrm{EOs}$ showed the lowest antifungal activity against $C$. mycophilum (Table 3). The activity of S. montana and T. vulgaris EOs differed significantly from the rest of the EOs $\left(\mathrm{F}_{4,59}=54.87 ; p=0.0\right)$. 
Table 3. Mean effective dose ( $\mathrm{ED}_{50}$ values $\pm \mathrm{SD}$ (standard deviation)) of essential oils for isolates of Cladobotryum mycophilum and Agaricus bisporus. Selectivity index (SI) between pathogen and host.

\begin{tabular}{|c|c|c|c|}
\hline \multirow[t]{2}{*}{ Essential Oil } & $\begin{array}{l}\text { Cladobotryum } \\
\text { mycophilum }(n=12)\end{array}$ & $\begin{array}{l}\text { Agaricus bisporus } \\
(n=4)\end{array}$ & \multirow[t]{2}{*}{ Selectivity Index } \\
\hline & $\mathrm{ED}_{50}\left(\mathrm{mg} \mathrm{L}^{-1}\right)$ & $\mathrm{ED}_{50}\left(\mathrm{mg} \mathrm{L}^{-1}\right)$ & \\
\hline Satureja montana & $42.8 \pm 33.4 \mathrm{ab}$ & $537.4 \pm 192.1 b$ & 0.08 \\
\hline Thymus vulgaris & $35.5 \pm 23.0 \mathrm{a}$ & $389.7 \pm 131.5 b$ & 0.09 \\
\hline Salvia lavandulifolia & $598.4 \pm 430.9 b$ & $587.1 \pm 177.4 b$ & 1.02 \\
\hline Thymus mastichina & $627.3 \pm 183.9 b$ & $175.7 \pm 60.2 \mathrm{a}$ & 3.57 \\
\hline Lavandula $\times$ intermedia & $784.2 \pm 460.5 b$ & $146.6 \pm 39.2 \mathrm{a}$ & 5.35 \\
\hline
\end{tabular}

a Selectivity index expressed as the ratio between the mean $\mathrm{ED}_{50}$ value of $C$. mycophilum for each essential oil and the corresponding mean $\mathrm{ED}_{50}$ value of $A$. bisporus. ${ }^{\mathrm{b}}$ Values followed by different lowercase letters in the columns indicate statistically significant differences at $p=0.05$ according to Fisher's LSD (least significant difference) test.

The in vitro antifungal activity of the EOs toward A. bisporus was highest in L. $\times$ intermedia $\left(\mathrm{ED}_{50}\right.$ $\left.=146.6 \mathrm{mg} \mathrm{L}^{-1}\right)$ and T. mastichina $\left(\mathrm{ED}_{50}=175.7 \mathrm{mg} \mathrm{L}^{-1}\right)$ and the least toxic EOs in this respect were S. lavandulifolia $\left(\mathrm{ED}_{50}=587.1 \mathrm{mg} \mathrm{L}^{-1}\right)$ and S. montana $\left(\mathrm{ED}_{50}=537.4 \mathrm{mg} \mathrm{L}^{-1}\right)($ Table 3). Lavandula $\mathrm{x}$ intermedia and T. mastichina EOs had significant differences from the rest of the $\mathrm{EOs}\left(\mathrm{F}_{4,19}=8.98\right.$; $p=0.0007)$. According to values obtained for selectivity index, S. montana and T. vulgaris EOs showed the best selective toxicity ( $\mathrm{SI}=0.08$ and 0.09 , respectively) between pathogen and host.

\subsection{Effectiveness of EOs Treatments in Mushroom Growing Trials with Cladobotryum mycophilum Inoculation}

In trial A, the first symptoms of cobweb were detected at the end of the first flush (day 28 after casing) in the IEO1B treatment, and in the second flush in IEO3B (day 31) and IEO1A (day 33) treatments. Cobweb symptoms in C and IC appeared 39 days after casing. By the end of the crop cycle, the disease incidence (DIcont) in the non-inoculated control (C) was $28.3 \%$. This DIcont may be due to cross-contamination incidents. In the inoculated control (IC), the DIcorr was $42.6 \%$. In the treatments IEO1B and IEO1A, the DIcorr was 73.2 and $47.3 \%$, respectively, while in IEO3B and IEO3A it was 26.7 and $24.4 \%$. By contrast, when metrafenone (IMTF) was used, the DIcorr was $0 \%$ at the end of the crop cycle. There were significant differences between IMTF and the rest of the treatments $\left(\mathrm{F}_{6,41}=5.54 ; p=0.0004\right)$ (Figure 1$)$. At the end of the crop cycle, the most effective treatments were metrafenone (IMTF) and T. vulgaris (IEO3A and IEO3B) showing significant differences with S. montana EO treatment (IEO1B) $\left(\mathrm{F}_{4,29}=6.52 ; p=0.0010\right)$ (Figure 2).

In trial B, the first symptom of disease was observed in treatment IC, 31 days after casing, at the end of the second flush, followed by treatments IEO1B ( 34 days) and IEO1A (35 days). Cobweb symptoms in $C$ appeared 46 days after casing. At the end of the crop cycle, the DIcont in the non-inoculated control (C) was $6.7 \%$. In the inoculated control (IC), the DIcorr was $31.8 \%$ (Figure 1). In treatments IEO1B and IEO1A, the DIcorr was 19.0 and 7.4\%, respectively, while in IEO3B and IEO3A it was 4.7 and $3.0 \%$. In the IMTF treatment it was $1.5 \%$. There were significant differences between IC and C, IMTF, IEO1A, IEO3B, and IEO3A treatments $\left(\mathrm{F}_{6,41}=3.2 ; p=0.0131\right)$ at the end of the crop cycle. The most effective treatments at the end of the crop cycle were those involving metrafenone (IMTF), S. montana $\mathrm{EO}$ (IEO1A) and T. vulgaris $\mathrm{EO}$ (IEO3B and IEO3A) $\left(\mathrm{F}_{4,29}=2.37 ; p=0.08\right)$ (Figure 2). 


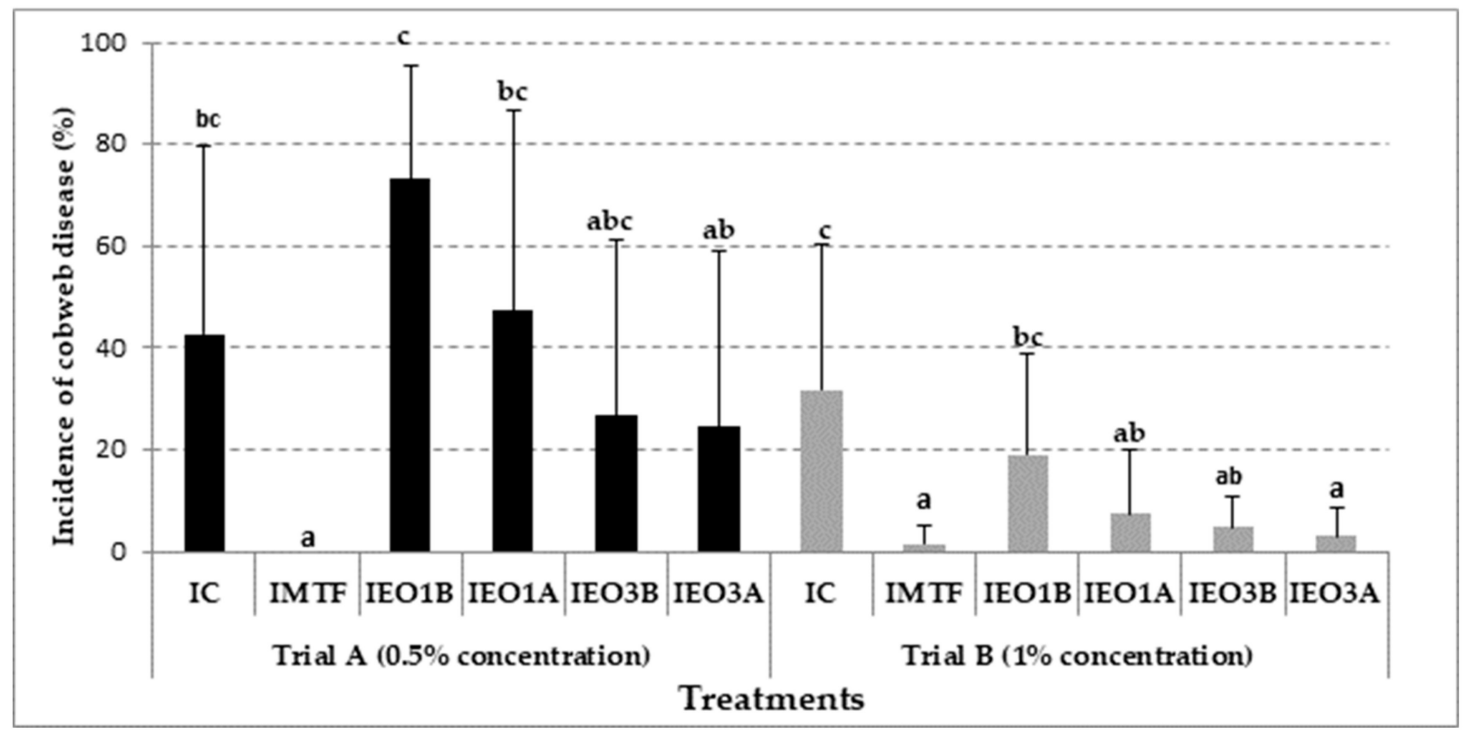

Figure 1. Incidence of cobweb disease (DIcorr) of different essential oils and fungicide treatments in two mushroom crop trials (A and B) with Cladobotryum mycophilum inoculation. Treatments are explained in Table 1. For each trial, different letters on columns indicate significant difference according to Fisher's LSD (least significant difference) test at $p=0.05$.

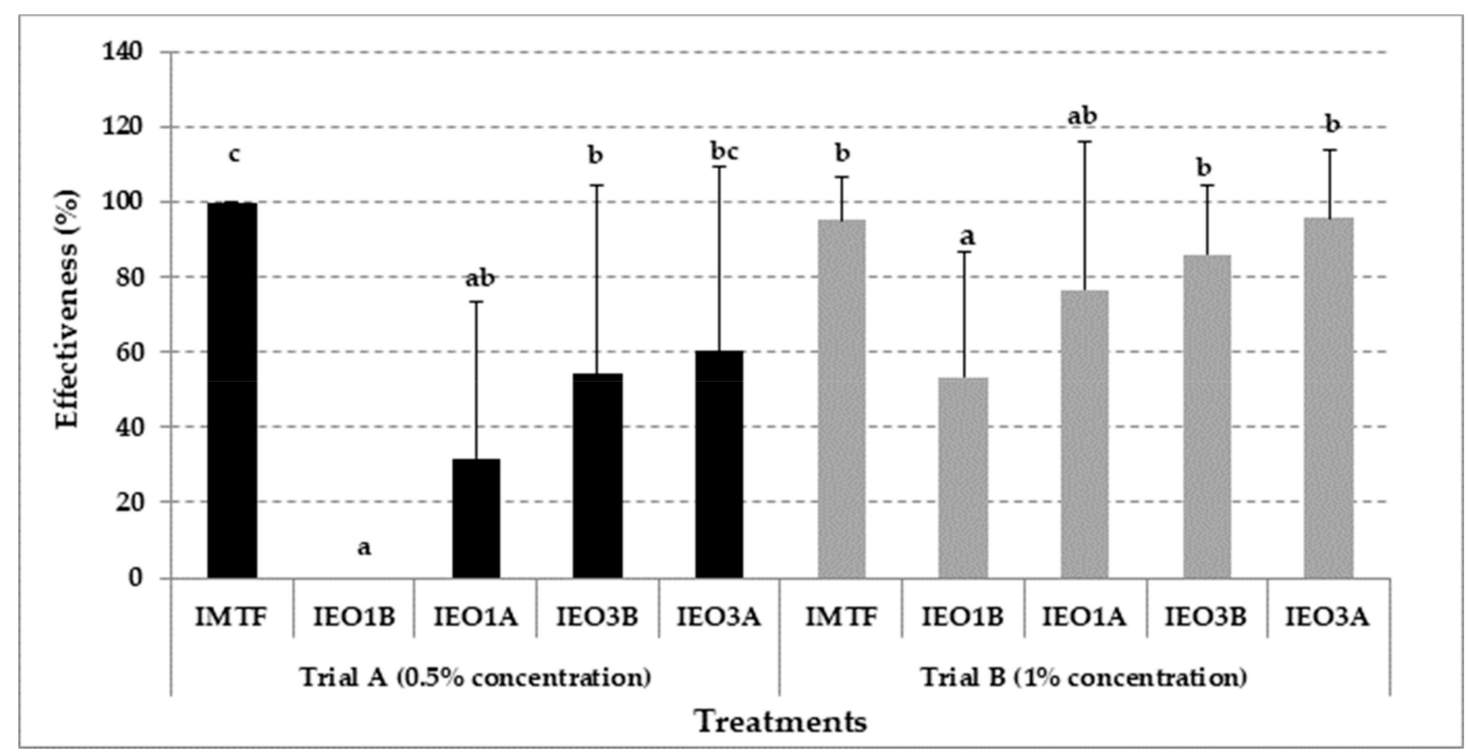

Figure 2. Effectiveness (EF) of different essential oils and fungicide treatments at the end of the crop cycle in two mushroom crop trials (A and B) with Cladobotryum mycophilum inoculation. Treatments are explained in Table 1. For each trial, different letters on columns indicate significant difference according to Fisher's LSD (least significant difference) test at $p=0.05$.

\subsection{Effect of EOs Treatments on Agaricus bisporus Yield}

In trial $\mathrm{C}$, metrafenone treatment (MTF) provided the highest yield at the first flush (Table 4), followed by the control (C), while treatments with essential oils applied after inoculation (EO1A and EO3A) had the lowest yield. The EO1A and EO3A treatments showed significant differences in yield from the rest of the treatments $\left(\mathrm{F}_{5,29}=5.55 ; p=0.0016\right)$. At the second flush, the opposite was the case, since the treatments with essential oils applied after inoculation (EO1A and EO3A) had the highest yield, while treatments $C$ and MTF had the lowest yields, with significant differences between EO3A and $\mathrm{C}, \mathrm{MTF}, \mathrm{EO} 1 \mathrm{~B}$, and $\mathrm{EO} 3 \mathrm{~B}\left(\mathrm{~F}_{5,29}=3.55 ; p=0.0152\right)$. At the end of the crop cycle, there were no 
significant differences between treatments in total yield or biological efficiency $\left(\mathrm{F}_{5,29}=0.73 ; p=0.6089\right)$. Regarding earliness, EO1B, EO3B, and EO3A showed a significant delay of 1 day compared with C and $\operatorname{MTF}\left(\mathrm{F}_{5,29}=16.32 ; p=0.0000\right)$.

Table 4. Effect of the essential oils and fungicide treatments on Agaricus bisporus quantitative production parameters.

\begin{tabular}{|c|c|c|c|c|c|}
\hline \multirow{2}{*}{ Treatments $^{a}$} & \multicolumn{3}{|c|}{ Mushroom Yield (kg m $\left.{ }^{-2}\right)$} & \multirow{2}{*}{$\begin{array}{l}\text { Biological Efficiency } \\
\text { (kg dt }{ }^{-1} \text { Compost) }\end{array}$} & \multirow{2}{*}{$\begin{array}{l}\text { Earliness (Days } \\
\text { from Casing) }\end{array}$} \\
\hline & 1st Flush & 2nd Flush & Total & & \\
\hline $\mathrm{C}$ & $11.0 \pm 3.8 \mathrm{bb}$ & $5.8 \pm 0.9 \mathrm{ab}$ & $16.8 \pm 3.4 \mathrm{a}$ & $67.1 \pm 13.8 \mathrm{a}$ & $24.0 \pm 0.2 \mathrm{a}$ \\
\hline MTF & $12.1 \pm 2.6 \mathrm{~b}$ & $5.0 \pm 0.6 \mathrm{a}$ & $17.1 \pm 2.8 \mathrm{a}$ & $68.4 \pm 11.1 \mathrm{a}$ & $23.9 \pm 0.3 \mathrm{a}$ \\
\hline EO1B & $9.4 \pm 1.1 \mathrm{~b}$ & $6.6 \pm 4.0 \mathrm{ab}$ & $16.0 \pm 3.9 \mathrm{a}$ & $64.1 \pm 15.4 \mathrm{a}$ & $25.4 \pm 0.3 c$ \\
\hline E01A & $6.1 \pm 2.2 \mathrm{a}$ & $9.1 \pm 2.6 \mathrm{bc}$ & $15.1 \pm 1.4 \mathrm{a}$ & $60.4 \pm 5.4 \mathrm{a}$ & $24.6 \pm 0.5 b$ \\
\hline EO3B & $10.7 \pm 1.3 b$ & $7.2 \pm 2.0 \mathrm{ab}$ & $18.0 \pm 1.8 \mathrm{a}$ & $71.7 \pm 7.2 \mathrm{a}$ & $25.2 \pm 0.3 c$ \\
\hline EO3A & $6.2 \pm 2.6 \mathrm{a}$ & $11.3 \pm 4.1 \mathrm{c}$ & $17.5 \pm 2.0 \mathrm{a}$ & $70.0 \pm 8.0 \mathrm{a}$ & $25.0 \pm 0.5 \mathrm{bc}$ \\
\hline SED & 1.08 & 1.22 & 1.2 & 4.81 & 0.16 \\
\hline LSD & 4.72 & 5.32 & 5.26 & 21.05 & 0.69 \\
\hline d.f. & 29 & 29 & 29 & 29 & 29 \\
\hline
\end{tabular}

a Treatments are explained in Table $1 .{ }^{b}$ Values followed by different lowercase letters in the columns indicate statistically significant differences at $p=0.05$ according to Fisher's LSD (least significant difference) test. SED: Standard error of the difference between two means. LSD: Least significant difference between two means. d.f.: Degrees of freedom associated with the LSD and SED.

The treatment of EOs had a strong negative effect on $A$. bisporus yield at the first flush when applied on day 13 after casing, with reductions of $45 \%$ and $44 \%$ in EO1A and EO3A, respectively, compared with the control C. These reductions were even greater compared with the yield obtained with MTF, the differences with EO1A and EO3A being statistically significant. However, in treatments applied 10 days after casing (EO1B and EO3B) the reduction in yield was less pronounced, 15\% and $3 \%$, respectively, compared with the control (C). Nevertheless, the yield obtained at the second flush compensated for the drop in production at the first flush, and all EO treatments provided higher yields than the control and MTF treatment (14\% increase in EO1B and 95\% in EO3A, compared with the control). At the end of crop cycle, neither the total production nor biological efficiency showed significant differences among the different treatments applied. As regards earliness, there was a slight delay (0.6-1.4 days) in the harvest of the first flush in all treatments involving EOs, with significant differences between the control $\mathrm{C}$ and MTF and EO1B, EO3B, and EO3A. In other words, the EO treatments had a strong fungitoxic effect during the first flush.

\section{Discussion}

The fungicidal effect of five EOs from Mediterranean aromatic plants on the mycopathogenic fungus C. mycophilum was assessed in this study. In vitro bioassays showed that S. montana and T. vulgaris EOs had the greatest inhibitory effect against C. mycophilum, while S. lavandulifolia, L. $\times$ intermedia and T. mastichina EOs were the least effective. The essential oils of S. montana and T. vulgaris were characterized by the phenolic compounds, carvacrol and thymol, which are consistent with the results of other studies [36,37]. Satureja montana contained a higher concentration of carvacrol (17.22\%) than the other essential oils. Thymol was the main component of T. vulgaris oil (25.78\%). These two EOs contained a significant proportion of biological precursors of the phenolic components, $\gamma$-terpinene and $p$-cymene. Carvacrol and thymol have been shown to have an important antifungal effect, causing damage in the cell membrane by interacting with sterols, particularly ergosterol [38,39]. However, the antifungal activity cannot be attributed to a single component, because there are many compounds acting synergistically $[37,40,41]$. For example, $\gamma$-terpinene and $p$-cymene, biological precursors of carvacrol, are not effective antibacterial agents when used alone, but, when combined with carvacrol, there is a synergism to facilitate the transport of carvacrol across the cytoplasmic membrane of fungi [41,42]. The essential oils of C. zeylanicum (cinnamon), O. vulgare (oregano), S. aromaticum (clove), Pogostemon cablin Benth. (patchouli), T. vulgaris (thyme), M. alternifolia (tea tree), Mentha piperita L. 
(peppermint), and Pelargonium graveolens L'Hér. (geranium) also showed antifungal activity against Cladobotryum sp. [22,43,44].

On the other hand, in vitro bioassays showed that S. lavandulifolia, S. montana, and T. vulgaris EOs were the least effective in inhibiting the mycelial growth of $A$. bisporus, while L. $\times$ intermedia and T. mastichina EOs were the most effective. In this case, the results were in contrast to those obtained in the bioassays with C. mycophilum. That is, the EOs of S. montana and T. vulgaris had greater antifungal activities against $C$. mycophilum than $A$. bisporus. These EOs, the only ones that contained thymol or carvacrol in their composition, showed no antifungal activity against $A$. bisporus. The reason for this low antifungal activity against $A$. bisporus may reflect the physiological trait of the mushroom to produce lignolytic enzymes, especially laccase and manganese peroxidase, which are able to decompose the phenolic compounds, while the materials produced by degradation are consumed by the mushroom $[18,45,46]$.

The antifungal activity of L. $\times$ intermedia $\left(\mathrm{ED}_{50}=146.6 \mathrm{mg} \mathrm{L}^{-1}\right)$ and T. mastichina $\mathrm{EOs}\left(\mathrm{ED}_{50}=\right.$ $175.7 \mathrm{mg} \mathrm{L}^{-1}$ ) against $A$. bisporus could be attributed to the content of alcoholic monoterpenoids, which include linalool and linalyl acetate [15,42]. Other essential oils, like M. alternifolia and P. graveolens EOs, also showed in vitro toxicity against $A$. bisporus $\left(\mathrm{ED}_{50}=98.0\right.$ and $128.36 \mathrm{mg} \mathrm{L}^{-1}$, respectively) $[18,22]$.

The fungitoxic selectivity between the pathogen (C. mycophilum) and the host (A. bisporus) expressed by the selectivity indexes of the tested EOs indicated that $S$. montana and T. vulgaris EOs were the most selective essential oils ( $\mathrm{SI}=0.08$ and 0.09 , respectively). These values (lower than 0.1 ) are better than those obtained in previous studies with the fungicides chlorothalonil and thiophanate-methyl (SI = 0.38 and 0.21 , respectively). However, the fungicides metrafenone, prochloraz-Mn, and thiabendazole showed better selectivity than the EOs tested ( $\mathrm{SI}=0.00001,0.0031$, and 0.01 , respectively) [13]. On the other hand, L. x intermedia and T. mastichina EOs had the greatest inhibitory effect against the A. bisporus mycelium, and their selectivity indexes were the highest (Table 3).

The results obtained using the two most selective essential oils, S. montana and T. vulgaris, in the cropping trials with inoculated treatments of $C$. mycophilum indicated that both EOs were effective when used at the higher doses ( $1 \%$ concentration) (Figure 2). The T. vulgaris (IEO3B, IEO3A) and S. montana (IEO1A) EOs treatments, at $1 \%$ concentration, were as effective as those involving metrafenone. Until now, the most effective treatment for controlling cobweb disease has been with metrafenone [13]. These results agree with those of previous studies carried out in mushroom growing rooms, which showed that the preventative use of T. vulgaris oil was able to control the development of wet bubble disease caused by Mycogone perniciosa in mushrooms with no detrimental effect on the growth of $A$. bisporus, and provided an overall yield similar to that following the application of a commercial fungicide [20]. On the other hand, there no were significant differences between EO treatments applied before and after inoculation with conidia of C. mycophilum.

\section{Conclusions}

According to the obtained results, S. montana and T. vulgaris EOs showed potent in vitro antifungal activity against $C$. mycophilum compared with other EOs tested. These EOs were characterized by the presence of phenolic compounds such as carvacrol and thymol which were absent in the other EOs tested. In addition, the fungitoxic selectivity between C. mycophilum and A. bisporus indicated that S. montana and T. vulgaris EOs were the most selective of the essential oils tested. When used in mushroom growing trials and applied at a later time compared with standard fungicide products, the two EOs tested showed some efficacy at controlling cobweb disease when used at the $1 \%$ rate, especially T. vulgaris, but additional trials are needed to confirm this observation. However, there was a strong fungitoxic effect at the first flush, which increased with the time of application nearing the harvest period, although at the end of the crop cycle there were no differences between treatments in terms of biological efficiency. These results suggest that T. vulgaris and S. montana essential oils may be efficacious in managing cobweb disease if used as part of an integrated pest management (IPM) program. 
Author Contributions: Conceptualization, F.J.G. and M.J.N.; data curation, F.J.G. and M.J.N.; formal analysis, M.J.N. and M.S.; funding acquisition, F.J.G.; investigation, F.J.G., F.D. and D.H.-P.; methodology, F.J.G. and D.H.-P.; project administration, F.J.G.; software, M.J.N.; supervision, M.S., F.D. and D.H.-P.; validation, M.S. and F.D.; writing—original draft, F.J.G. and M.J.N.; writing—review and editing, F.J.G. and M.J.N.

Funding: This research was funded by INIA (Ministry of Science, Innovation and Universities, Spain) and FEDER, Project E-RTA2014-00004-C02-01.

Acknowledgments: The authors are grateful to the INIA (Ministry of Science, Innovation and Universities, Spain), FEDER and Patronato Desarrollo Provincial (Diputación de Cuenca, Spain) who have supported this research.

Conflicts of Interest: The authors declare no conflict of interest.

\section{References}

1. Grogan, H.M.; Gaze, R.H. Fungicide resistance among Cladobotryum spp.-causal agents of cobweb disease of the edible mushroom Agaricus bisporus. Mycol. Res. 2000, 104, 357-364. [CrossRef]

2. Fletcher, J.T.; Gaze, R.H. Mushroom Pest and Disease Control; Manson Publishing: London, UK, 2008.

3. Largeteau, M.L.; Savoie, J.M. Microbially induced diseases of Agaricus bisporus: Biochemical mechanisms and impact on commercial mushroom production. Appl. Microbiol. Biotechnol. 2010, 86, 63-73. [CrossRef]

4. Carrasco, J.; Navarro, M.J.; Gea, F.J. Cobweb, a serious pathology in mushroom crops: A review. Span. J. Agric. Res. 2017, 15, 19. [CrossRef]

5. Chakwiya, A.; Van der Linde, E.J.; Chidamba, L.; Korsten, L. Diversity of Cladobotryum mycophilum isolates associated with cobweb disease of Agaricus bisporus in the south African mushroom industry. Eur. J. Plant Pathol. 2019, 154, 767-776. [CrossRef]

6. Back, C.G.; Lee, C.Y.; Seo, G.S.; Jung, H.Y. Characterization of species of Cladobotryum which cause cobweb disease in edible mushrooms grown in Korea. Mycobiology 2012, 40, 189-194. [CrossRef]

7. Kim, M.K.; Lee, Y.H.; Cho, K.M.; Lee, J.Y. First report of cobweb disease caused by Cladobotryum mycophilum on the edible mushroom Pleurotus eryngii in Korea. Plant Dis. 2012, 96, 1374. [CrossRef] [PubMed]

8. Gea, F.J.; Carrasco, J.; Suz, L.M.; Navarro, M.J. Characterization and pathogenicity of Cladobotryum mycophilum in Spanish Pleurotus eryngii mushroom crops and their sensitivity to fungicides. Eur. J. Plant Pathol. 2017, 147, 129-139. [CrossRef]

9. Gea, F.J.; Navarro, M.J.; Suz, L.M. Cobweb disease on oyster culinary-medicinal mushroom (Pleurotus ostreatus) caused by the mycoparasite Cladobotryum mycophilum. J. Plant Pathol. 2019, 101, 349-354. [CrossRef]

10. Carrasco, J.; Navarro, M.J.; Santos, M.; Diánez, F.; Gea, F.J. Identification, incidence and pathogenicity of Cladobotryum mycophilum, causal agent of cobweb disease on Agaricus bisporus mushroom crops in Spain. Ann. Appl. Biol. 2016, 168, 214-224. [CrossRef]

11. Adie, B.; Grogan, H.; Archer, S.; Mills, P. Temporal and spatial dispersal of Cladobotryum conidia in the controlled environmental of a mushroom growing room. Appl. Environ. Microbiol. 2006, 72, 7212-7217. [CrossRef] [PubMed]

12. Pyck, N.; Grogan, H. Fungal Diseases of Mushrooms and Their Control, MushTV Publications (Factsheet 04/15). 2015. Available online: http://horticulture.ahdb.org.uk/mushtv-publications (accessed on 12 May 2017).

13. Carrasco, J.; Navarro, M.J.; Santos, M.; Gea, F.J. Effect of five fungicides with different modes of action on cobweb disease (Cladobotryum mycophilum) and mushroom yield. Ann. Appl. Biol. 2017, 171, 62-69. [CrossRef]

14. Lang, G.; Buchbauer, G. A review on recent research results (2008-2010) on essential oils as antimicrobials and antifungals. A review. Flavour Fragr. J. 2012, 27, 13-39. [CrossRef]

15. Nazzaro, F.; Fratianni, F.; Coppola, R.; De Feo, V. Essential oils and antifungal activity. Pharmaceuticals 2017, 10, 86. [CrossRef] [PubMed]

16. Diánez, F.; Santos, M.; Parra, C.; Navarro, M.J.; Blanco, R.; Gea, F.J. Screening of antifungal activity of twelve essential oils against eight pathogenic fungi of vegetables and mushroom. Lett. Appl. Microbiol. 2018, 67, 400-410. [CrossRef]

17. Soković, M.; van Griensven, L.J.L.D. Antimicrobial activity of essential oils and their components against the three major pathogens of the cultivated button mushroom, Agaricus bisporus. Eur. J. Plant Pathol. 2006, 116, 211-224. [CrossRef] 
18. Mehrparvar, M.; Goltapeh, E.M.; Safaie, N.; Ashkani, S.; Hedesh, R.M. Antifungal activity of essential oils against mycelial growth of Lecanicillium fungicola var. fungicola and Agaricus bisporus. Ind. Crops Prod. 2016, 84, 391-398. [CrossRef]

19. Santos, T.L.; Belan, L.L.; Zied, D.C.; Dias, E.S.; Alves, E. Essential oils in the control of dry bubble disease in white button mushroom. Cienc. Rural 2017, 47, e20160780. [CrossRef]

20. Regnier, T.; Combrinck, S. In vitro and in vivo screening of essential oils for the control of wet bubble disease of Agaricus bisporus. S. Afr. J. Bot. 2010, 76, 681-685. [CrossRef]

21. Idrees, M.; Sossah, F.L.; Yang, Y.; Li, D.; Li, S.; Fu, Y.; Li, Y. Identification of resistance to cobweb disease caused by Cladobotryum mycophilum in wild and cultivated strains of Agaricus bisporus and screening for bioactive botanicals. RSC Adv. 2019, 9, 14758-14765.

22. Potočnik, I.; Vukojević, J.; Stajić, M.; Rekanović, E.; Stepanović, M.; Milijašević, S.; Todorović, B. Toxicity of biofungicide Timorex 66 EC to Cladobotryum dendroides and Agaricus bisporus. Crop Prot. 2010, 2, 290-294. [CrossRef]

23. Santana, O.; Cabrera, R.; Giménez, C.; González-Coloma, A.; Sánchez-Vioque, R.; de los Mozos-Pascual, M.; Rodríguez-Conde, M.F.; Laserna-Ruiz, I.; Usano-Alemany, J.; Herraiz, D. Chemical and biological profiles of the essential oils from aromatic plants of agro-industrial interest in Castilla-La Mancha (Spain). Grasas $Y$ Aceites 2012, 63, 214-222.

24. Ortiz de Elguea-Culebras, G.; Sanchez-Vioque, R.; Berruga, M.I.; Herraiz-Peñalver, D.; González-Coloma, A.; Andrés, M.F.; Santana-Méridas, O. Biocidal potential and chemical composition of industrial essential oils from Hyssopus officinalis, Lavandula $x$ intermedia var. super, and Santolina chamaecyparissus. Chem. Biodivers. 2018, 15, e1700313. [CrossRef] [PubMed]

25. Raut, J.S.; Karuppayil, S.M. A status review on the medicinal properties of essential oils. Ind. Crops Prod. 2014, 62, 250-264. [CrossRef]

26. Xie, Y.; Wang, Z.; Huang, Q.; Zhang, D. Antifungal activity of several essential oils and major components against wood-rot fungi. Ind. Crops Prod. 2017, 108, 278-285. [CrossRef]

27. Council of Europe. European Pharmacopoeia, 3rd ed.; Council of Europe: Strasbourg, France, 1996.

28. Adams, R.P. Quadrupole Mass Spectra of Compounds Listed in order of Their Retention Time on DB-5. Identification of Essential Oils Components by Gas Chromatography/Quadrupole Mass Spectroscopy; Allured Publishing Co.: Carol Stream, IL, USA, 2001; p. 456.

29. Gams, W.; Hoozemans, A.C.M. Cladobotryum-Konidienformen von Hypomyces-Arten. Persoonia 1970, 6 , 95-110.

30. Rogerson, C.T.; Samuels, G.J. Agaricicolous species of Hypomyces. Mycologia 1994, 86, 839-866. [CrossRef]

31. Robertson, J.L.; Preisler, J.K.; Russell, R.M. Polo Plus. Probit and Logit Analysis. User's Guide; LeOra Software: Petulama, CA, USA, 2002.

32. Gea, F.J.; Santos, M.; Diánez, F.; Tello, J.C.; Navarro, M.J. Effect of spent mushroom compost tea on mycelial growth and yield of button mushroom (Agaricus bisporus). World J. Microbiol. Biotechnol. 2012, 28, 2765-2769. [CrossRef] [PubMed]

33. Chrysayi-Tokousbalides, M.; Kastanias, M.A.; Philippoussis, A.; Diamantopoulou, P. Selective fungitoxicity of famoxadone, tebuconazole and trifloxistrobin between Verticillium fungicola and Agaricus bisporus. Crop Prot. 2007, 26, 469-475. [CrossRef]

34. Rosenhein, J.A.; Hoy, M. Confidence intervals for Abbott's Formula correction of bioassay data for control response. J. Econ. Entomol. 1989, 82, 331-335. [CrossRef]

35. Abbott, W.S. A method of computing the effectiveness of an insecticide. J. Econ. Entomol. 1925, 18, $265-267$. [CrossRef]

36. Lee, S.O.; Choi, G.J.; Jang, K.S.; Lim, H.K.; Cho, K.Y.; Kim, J.C. Antifungal activity of five plant essential oils as fumigant against postharvest and soil borne plant pathogenic fungi. Plant Pathol. J. 2007, 23, 97-102. [CrossRef]

37. Stević, T.; Berić, T.; Šavikin, K.; Soković, M.; Gođevac, D.; Dimkić, I.; Stanković, S. Antifungal activity of selected essential oils against fungi isolated from medicinal plant. Ind. Crops Prod. 2014, 55, 116-122. [CrossRef]

38. Lima, I.O.; de Oliveira Pereira, F.; de Oliveira, W.A.; de Oliveira Lima, E.; Menezes, E.A.; Cunha, F.A.; de Fátima, M.F.M.D. Antifungal activity and mode of action of carvacrol against Candida albicans strains. J. Essent. Oil Res. 2013, 25, 138-142. [CrossRef] 
39. Chavan, P.S.; Tupe, S.G. Antifungal activity and mechanism of action of carvacrol and thymol against vineyard and wine spoilage yeasts. Food Control 2014, 46, 115-120. [CrossRef]

40. Moon, H.; Rhee, M.S. Synergism between carvacrol or thymol increases the antimicrobial efficacy of soy sauce with no sensory impact. Int. J. Food Microbiol. 2016, 217, 35-41. [CrossRef]

41. Thomidis, T.; Filotheou, A. Evaluation of five essential oils as bio-fungicides on the control of Pilidiella granati rot in pomegranate. Crop Prot. 2016, 89, 66-71. [CrossRef]

42. Ultree, A.; Bennink, M.H.J.; Moezelaar, R. The phenolic hydroxyl group of carvacrol is essential for action against the food-borne pathogen Bacillus cereus. Appl. Environ. Microbiol. 2002, 68, 1561-1568. [CrossRef]

43. Tanović, B.; Potočnik, I.; Delibašic, G.; Ristić, M.; Kostić, M.; Marković, M. In vitro effect of essential oils from aromatic and medicinal plants on mushroom pathogens: Verticillium fungicola var. fungicola, Mycogone perniciosa, and Cladobotryum sp. Arch. Biol. Sci. 2009, 61, 231-237. [CrossRef]

44. Luković, J.; Stepanović, M.; Todorović, B.; Milijašević-Marčić, S.; Duduk, N.; Vico, I.; Potočnik, I. Antifungal activity of cinnamon and clove essential oils against button mushroom pathogens Cladobotryum dendroides (Bull.) W. Gams \& Hooz. and Lecanicillium fungicola var. fungicola (Preuss) Hasebrauk. Pestic. I Phytomed. 2018, 33, 19-26.

45. Savoie, J.M. Changes in enzyme activities during early growth of the edible mushroom, Agaricus bisporus, in compost. Mycol. Res. 1998, 102, 1113-1118. [CrossRef]

46. Chen, Y.; Chefetz, B.; Rosario, R.; Heemst, J.D.H.V.; Romaine, C.P.; Hatcher, P.G. Chemical nature and composition of compost during mushroom growth. Compost Sci. Util. 2000, 8, 347-359. [CrossRef]

(C) 2019 by the authors. Licensee MDPI, Basel, Switzerland. This article is an open access article distributed under the terms and conditions of the Creative Commons Attribution (CC BY) license (http://creativecommons.org/licenses/by/4.0/). 